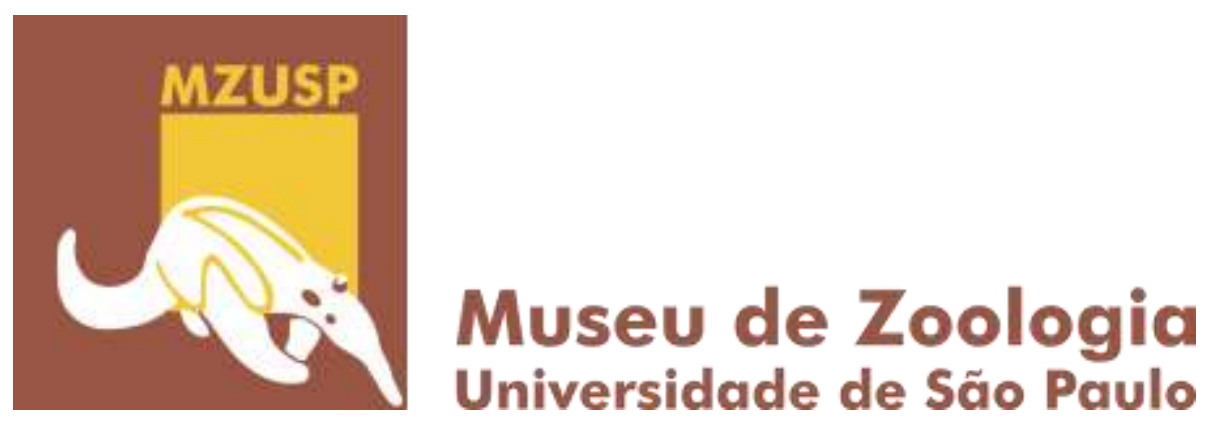

Vinícius Corrêa Espíndola

\title{
Phylogenetic relationship of the Anguilliformes (Teleostei: Elopomorpha) with an emphasis in cephalic morphology
}

Relações filogenéticas em Anguilliformes (Teleostei: Elopomorpha) com ênfase na morfologia cefálica 
Vinicius Corrêa Espíndola

\section{Phylogenetic relationship of the Anguilliformes (Teleostei: Elopomorpha) with an emphasis in cephalic morphology}

\section{Relações filogenéticas em Anguilliformes (Teleostei: Elopomorpha) com ênfase na morfologia cefálica}

Original Version

Thesis presented to the Post-Graduate Program of the Museu de Zoologia da Universidade de São Paulo to obtain the degree of Doctor of Science (Systematics, Animal Taxonomy and Biodiversity).

Advisor: Mario César Cardoso de Pinna, PhD. 
I do not authorize the reproduction and dissemination of this work in part or entirely by any electronic or conventional means.

Serviço de Biblioteca e Documentação

Museu de Zoologia da Universidade de São Paulo

\section{Cataloging in Publication}

Espíndola, Vinícius Corrêa

Phylogenetic relationship of the Anguilliformes (Teleostei: Elopomorpha) with an emphasis in cephalic morphology $=$ Relações filogenéticas em Anguilliformes (Teleostei: Elopomorpha) com ênfase na morfologia cefálica / Vinícius Corrêa Espíndola; Orientador Prof. Dr. Mário César Cardoso de Pinna. — São Paulo, 2019.

$312 \mathrm{p}$.

Tese (Doutorado) - Programa de Pós-Graduação em Sistemática, Taxonomia e Biodiversidade, Museu de Zoologia, Universidade de São Paulo, 2019.

Versão original. 
ESPÍNDOLA, Vinicius Corrêa

Phylogenetic relationship of the Anguilliformes (Teleostei: Elopomorpha) with an emphasis in cephalic morphology

Relações filogenéticas em Anguilliformes (Teleostei: Elopomorpha) com ênfase na morfologia cefálica

Tese apresentada ao Programa de Pós-Graduação do Museu de Zoologia da Universidade de São Paulo para obtenção do título de Doutor em Ciências (Sistemática, Taxonomia Animal e Biodiversidade).

Aprovado:

Instituição:

Prof. Dr.

Assinatura:

Julgamento:

Instituição:

Julgamento:

Assinatura:

Prof. Dr.

Instituição:

Julgamento:

Assinatura:

Prof. Dr.

Instituição:

Julgamento:

Assinatura:

Prof. Dr.

Instituição:

Julgamento:

Assinatura: 


\section{ACKNOWLEDGMENTS}

Nessa seção vou agradecer em palavras coisas que não tem como expressar somente em texto, mas tentarei.

Aos meus pais, Lodson Espíndola e Anna Corrêa Espíndola (in memoriam), que foram os principais responsáveis pela formação intelectual e afetiva, razão pela qual eles devem vir em primeiro lugar com toda justiça. Assim como meu irmão e minha sobrinha, Lodson e Mariana, os quais me deram apoio em horas alegres e difíceis, com sorrisos e carinho.

À minha esposa, Thaisi, sempre com carinho e amor, que em nenhum momento me deixou abaixar a cabeça e levantou sempre a minha motivação em qualquer hora do dia, mesmo nas horas que ficava calado pensando na tese. Os Andias também são meus e me ajudaram demais.

Ao meu guia acadêmico e amigo Mário de Pinna (papis), pela oportunidade de trabalhar, estudar, pensar e bater papo sobre cinema, política, comida, filogenia, morfologia, peixes e tudo mais.

Ao grande amigo e lenda viva, Náercio, na qual eu já vinha no caminho pensando em conversar sobre todas as atualidades possíveis (eu sempre o interrompia na lupa). Os esportes sempre foram os papos iniciais, nossas paixões por futebol e basquete guiaram esses anos (tiveram mais coisas também).

Herr Professor Britski, também teve um grande peso nesses momentos alegres do MZUSP, falando alemão, curiosidades da ictiologia, histórias sobre a ciência, Corumbataí, acordar tarde, qualidades em tomar leite enquanto todos tomavam café.

Ao cansado e competente Aléssio, que sempre foi extremamente gentil quando eu chegava com as coisas mais complicadas de Anguilliformes e ele falava: "Cara, esses bichos são muito loucos".

Aos amigos e companheiraços: Vaca que ajudou revisando textos, analises, gráficos, fotos e caminhadas até o metrô; Vitin, que mesmo distante me ajudou desde o início; Dagosta que apesar de me chutar, foi amigo de todas as horas (principalmente nas madrugadas); Pay que perdeu mais cabelos do que Paysandu perde jogos por ano; Marcelo Melo, que mesmo discordando de tudo, gosto de falar com ele; Motito que come mais do que do que hiena depois da seca; Sad, que dançava e tossia e pagava seus micos não intencionais; Manu, mesmo sendo brava me ajudou demais; Miguel, sempre disposto a ajudar e ... correr pelo laboratório; 
Camelier, que sempre me dava bronca pra levantar a cabeça; João Gabriel, que entendia minhas piadas; Paulo, por ser amigaço no Smithsonian e defender depois da minha tese e não me humilhar nas ilustrações; Tulio, que sempre foi mais feio; Cabelinho, sempre me pedindo carregador, caneta, lápis, durex... Marina, por colocar trilha sonora quando eu chegava Arthurzim, por não assistir meus vídeos; Guilhermão, por estar sempre presente e feliz; Pupo, por ser amigaço de todas as horas; Vitor, por reler meu caráteres e me dar excelentes dicas; Rodrigo Caires, por me esclarecer dúvidas e estar sempre presente ao meu lado; Gustavito, quando não assobiava. Aos novos integrantes do MZUSP, Pericles, George e Luz! Posso agradecer ao Osvaldo ou ele vai me xingar?

Ao meu primeiro ídolo na ictiologia, o qual tive a realização de conhecer, de ficar amigo, chamá-lo para publicar e, ainda, ser chamado para revisar um artigo seu, Dave Johnson. Passei apenas seis meses em seu laboratório, mas me senti muito em casa, amparado pela sua experiência, excelente humor e carinho. Melhor casal do NMNH, disparado, ainda mais quando a Ai cantava Bom Jovi e Dave observa de longe. Conto os dias para que novas conversas voltem e possa realizar minhas novas imitações. Carol e Lynne foram espetaculares e as conversas do almoço eram as melhores. Bruce e Springer me deram a total vontade de trabalhar acima de 80 anos, com alta produção. As conversas, no final de tarde, com Tom foram excepcionais, até entendi o sotaque Short a" nasal system. A gentileza do Jeff Clayton sempre querendo ajudar e ser prestativo. Jeff Williams sempre sorrindo e ajudando com as melhores dicas. Temos que falar da Krys Murphy que foi incrível comigo, praticamente me pegou no colo, assim como Sandra Raerodon, sempre procupada com a nossa volta na neve tarde. Ao mais do que famoso Obi-wan Kenobi da ictiologia, Dave Smith, foi primordial para que eu entendesse muita coisa em Anguilliformes e me mostrou umas coisas ainda não descritas, no MSC. David e Bill foram pessoas boas demais, Bill foi por muito tempo e sistema de alarme contra o Fernando, infelizmente o tempo foi muito curto e gostaria de conviver mais com ele, excelentes histórias saíram dali.

Ao Mark Sabaj e Mairangeles que me receberam no ANSP de braços abertos e me ajudaram demais nas tardes frias na Filadéfia. Até a parte principal, comer o cheesesteak.

Andrew Wilkinson (MCZ) foi uma pessoa excelente em me deixar mexer no material raro, enviar fotos de Neocyema, além de me levar para almoçar.

Eric Hilton (VIMS), Ben Frable and Phil Hastings (Sio); Rob Robins (UF) Kevin (FSBC), Flavio Lima (Zuec) e Lucena (PUCRS) Hans Ho (NMMB) pela ajuda em enviar 
matérias tão importantes para chegar ao final com excelentes resultados. Agradecer muito ao Nakae (NSMT), por me ajudar quando eu iria ser deportado do Japão.

Ao Marcelo Britto, meu ex-orientador, sempre foi atencioso, gentil, porém anda com um péssimo gosto para cinema. Ao Leandro, elfo com suas grandes correções nos textos com seus olhos de lince e ao Cris que não me deu um livro somente.

Também fica eu meu carinho pelo pessoal do museu: Aline, Nathalia, Dione, Eliane, Marta, Sonia e Mariana.

Meus amigos que não tiveram participação direta aqui, mas estão no meu coração.

Este trabalho contou com os seguintes apoios financeiros: Coordenação de Aperfeiçoamento do Ensino Superior (CAPES). 
Anguilliformes are a group of Teleostei fish with more than 1,000 species and 20 families. They were commonly known as eels, congers, and morays. The lack of consensus about the relationship hypotheses of a group in the last 40 years has mostly resulted from a lack of comprehensive studies bringing all families. Our study exposed the proposal for an integrated study of osteology and cephalic muscle and gill arches as a promising new source of characters to understand the intrarelationships of families which compound the order. With 108 terminal taxa, including representants of the 20 Anguilliformes families, the present study realized the most extensive morphological analysis ever made with the group, totalizing 248 phenotypic characters. The results generated a topology which the Anguilliformes order had strong support with 28 synapomorphies, indicating Protanguilla basal position been a sister group of remaining members of the order. One clade compound by long snout eels presented for the first time on the present study, which "Saccopharyngoidei" shared nine characteristics with Nemichthyidae. Synaphobranchidae grouped with "Chlopsidae" (not recovered as a monophyletic group), Myrocongridae and Muraenidae, a new arrangement with support of two synapomorphies non-ambiguous. The present work also clarified the homology problem, such as palatine absent in Anguilliformes, opercle sutured to hyomandibular, interopercle associated to levator operculi, adductor mandibulae segmentum facialis and adductor hyomandibulae (= elevator muscles) identified in Saccopharyngoidei. Moreover, we observed the presence of some structure, still present in the remaining representants, not only found in Protangilla, as pre-maxillae in Derichthys and gill rakers in Heterocongrinae. The results pointed out that muscles characters were an essential source in clarifying Anguilliformes relationships. 


\section{RESUMO}

Os Anguilliformes são um grupo de peixes teleósteos, com cerca de 1000 espécies e 20 famílias, popularmente conhecidos como enguias, congros e moreias. A ausência de consenso sobre as hipóteses de relações no grupo, durante os últimos 40 anos, decorreu em grande medida da falta de estudos abrangentes que reunissem todas as famílias. Nossa pesquisa expõe a proposta de um estudo integrado de osteologia e musculatura cefálica e dos arcos branquiais, como uma nova e promissora fonte de caracteres para entender as relações entre as famílias que compõem a ordem. Com 108 táxons terminais, incluindo representantes de todas as vinte famílias de Anguilliformes, o presente estudo realizou a maior análise morfológica já feita com o grupo, totalizando 248 caracteres fenotípicos. Os resultados geraram uma topologia na qual a ordem Anguilliformes tem um grande suporte de 28 sinapormorfias, indicando a posição basal de Protanguilla sendo grupo irmão dos demais membros da ordem. Um clado composto por enguias de focinho longo foi apresentado pela primeira vez no atual estudo, na qual os "Saccopharyngoidei" tiveram nove características compartilhadas com Nemichthyidae. Os Synaphobranchidae foram agrupados com "Chlopsidae" (não recuperado como grupo monofilético), Myrocongridae e Muraenidae, um arranjo inédito para a ordem com suporte de duas sinapomorfia não ambíguas. O presente estudo ainda esclareceu problemas de homologia, como a ausência de palatino em Anguilliformes, opérculo suturado a hiomandíbula, interopérculo associado ao levator operculi, adductor mandibulae segmentum facialis e adductor hyomandibulae identificados em Saccopharyngoidei. Além disso, observarmos a presença de algumas estruturas, ainda presentes nos demais representantes, não somente em Protanguilla, como: pré-maxilla presente em Derichthys e rastros branquiais em Heterocongrinae. $\mathrm{O}$ resultado aponta que os caracteres musculares foram uma fonte importante nos esclarecimentos sobre as relações de parentesco de Anguilliformes. 


\section{LISTA DE FIGURAS}

Figure 1 - Morphological variation in six families of Anguilliformes: A, Serrivomeridae (photo from fishbiosystem); B, Nemichthyidae (photo from Wikipedia); C, Cyematidae (photo from Andrew Wilkinson); D, Synaphobranchidae (photo from Fishes of Australia); E, Muraenidae (photo from gooddive.com); F, Saccopharyngidae (photo from digitalfishlibrary.org)

Figure 2 - Illustrations of leptocephalus larvae of meso- and bathypelagic eels families: A, Cyema; B, "Leptocephalus holti"; C, Monognathidae (metamorphic stage); D, Unidentified saccopharyngiform; E, Saccopharynx; F, Eurypharynx; G, Serrivomer beani; H, Nemichthys curvirostris; I, Avocettina infans; J, Derichthys serpentinus; K, Nessorhamphus ingolfianus. Illustrations A, C, D, and F to K are modified from Böhlke (1989), B is modified from Smith \& Miller (1996), and E is modified from Castle (1984).

Figure 3 - Hypotheses of the relationships of Anguilliformes inferred from morphological characters according to (A) Morphological phylogeny of Patterson and Rosen (1977), (B) morphological phylogeny of Robins (1989), and (C) combined morphological and molecular phylogeny (12S, 16S, 28S) of Forey et al. (1996); (figure modified from Santini et al. 2014) 235

Figure 4 - Hypothesis of the relationships of Anguilliformes inferred from morphological characters according to Belouze (2002); most parsimonious analysis based on osteology and morphology data, including six Cretaceous fossil and Osteoglossomorpha .235 
Figure 5 - Hypothesis of the relationships of Anguilliformes inferred from morphological characters, according to Johnson et al. (2012). Time tree of Anguilliformes and outgroup estimated from molecular-clock analysis. The analysis comprises molecular and morphological.

Figure 6 - Hypothesis of the relationships of Anguilliformes inferred from morphological characters according to from Obermiller \& Pfeifer (2003) most parsimonious (MP) tree for the combined $12 \mathrm{~S}$ and $16 \mathrm{~S}$ rRNA data set (Branch and Bound algorithm)

Figure 7 - Hypothesis of the relationships of Anguilliformes inferred from morphological characters according to Filleul \& Lavoué (2002), using on molecular data from rRNA 18S, 16S and $12 \mathrm{~S}$ a .240

Figure 8 - Hypothesis of the relationships of Anguilliformes inferred from morphological characters according to Tang \& Fielitz (2012) based on likelihood score. Muraenidae highlighted by the authors. 241

Figure 9 - Hypothesis of the relationships of Anguilliformes inferred from morphological characters according to Santini et al. (2013). Maximum likelihood phylogeny of Anguilliformes 242

Figure 10 - Hypothesis of the relationships of Anguilliformes inferred from morphological characters, according to Chen et al. (2014). The analysis performed was a maximum-likelihood tree of the combined dataset ( 3 nuclear and 3 mitochondrial genes, 4,601 bp in length)......243 
Figure 11 - Hypothesis of the relationships of Anguilliformes inferred from morphological characters according to Poulsen et al. (2018). Mitogenomic phylogenetic tree of 79 taxa of the Elopomorpha based on 13 protein-coding genes in the mitochondrial genome (ML and $\begin{array}{llll}\text { Bayesian } & \text { analyses, } & 11,700 & \text { base }\end{array}$ 244

Figure 12 - Neurocranium of (A) Cyema atrum USNM 208058 and (B) Echidna nebulosa $\mathrm{BMNH}$ uncat in dorsal view. 246

Figure 13 - Neurocranium of (A) Serrivomer beami, USNM 271046, and (B) Protanguilla palau, USNM 396016, in dorsal view. Scale bar: $1 \mathrm{~mm}$ 247

Figure 14 - Neurocranium of (A) Echidna nebulosa, BMNH uncat., and (B) Protanguilla palau, USNM 396016, in lateral view. Scale bar: $1 \mathrm{~mm}$. 248

Figure 15 - Neurocranium of (a) Protanguilla palau, USNM 396016, and (b) Simenchelys parasiticus, USNM 326917, midportion lateral view. Caudal Skeleton of (c) P. palau, USNM 396016, (d) Anguilla rostrata, USNM 106563, in lateral view. PU2, preural centrum 2; H, hypurals (Photo was taken from Johnson et., 2012: Figure 4). 249

Figure 16 - Jaw of Anguilla rostrata, USNM 106563, in ventral view. (Photo was taken by Ai Nonaka) 250 
Figure 17 - Suspensorium of Synaphobranchus sp., USNM uncat, in lateral view. (Photo taken by Ai Nonaka)

Figure 18 - Suspensorium of Serrivomer beami, USNM 271046, in lateral view. .251

Figure 19 - Neurocranium of Elops saurus, USNM 271046, in lateral view (Photo modified from Ridewood, 1904: Fig. 8c). 252

Figure 20 - Supensorium of Elops saurus in lateral view. (Photo modified from Ridewood, 1904: Fig. 10c) 252

Figure 21 - Neurocranium of Derichthys serpentinus, USNM 315025, in dorsal view.... .253

Figure 22 - Supensorium of Simenchelys parasitica, USNM 326917, in lateral view. .253

Figure 23 - Upper jaw of (A) Bathyuroconger vicinus, USNM 179070 and (B) Coloconger meadi, USNM 193572, in ventral view, showing the connection between ectopterygoid and ethmovomer. 254

Figure 24 - Cephalic and anterior portion of Anguilla rostrata, USNM 106563, in lateral view (Photo taken by Ai Nonaka). .255

Figure 25 - Jaw of Protanguilla palau, USNM 396016, in lateral view (Photo taken by Ai Nonaka) 255 
Figure 26 - Suspensorium of Protnguilla palau USNM 396016, in lateral view. .256

Figure 27 - Hyoid arch with the musculature of Albula vulpes, USNM 218871, in dorsal view. 257

Figure 28 - Hyoid arch of (A) Cyema atrum, ANSP 143871, (Leptocephalus), and (B) Anarchias similis, USNM 320964, in dorsal view. .257

Figure 29 - Branchial arches of Simenchelys parasitica, USNM 326917, in dorsal view. Scale bar: $2 \mathrm{~mm}$ 258

Figure 30 - Branchial arches (ventral elements) of Protanguilla palau, USNM 396016, in dorsal view (Photo taken by Ai Nonaka). 259

Figure 31 - Branchial arches (dorsal elements) of Protanguilla palau, USNM 396016, in dorsal view (Photo taken by Ai Nonaka) .259

Figure 32 - Neurocranium of Aldrovandia affinis (Kanehira et al. 2012: figure 2) in dorsal (above), lateral (middle) and ventral (below) views. AP, anterior process; AVP, anteroventral process; $\mathrm{BO}$, basioccipital; $\mathrm{CC}$, cartilage $\mathrm{C}$; $\mathrm{CD}$, cartilage $\mathrm{D}$; DET, dermethmoid; EC, ethmoid cartilage; EO, exoccipital; EP, epiotic; ET, ethmoid; F, frontal; LAP, lateral process; LP, lower process; PA, parietal; PAS, parasphenoid; PDP, posterodorsal process; PR, prootic; PT, pterotic; PTS, pterosphenoid; SO, supraoccipital; SP, sphenotic; UP, upper process; V, vomer; VP, ventral process. Scale bar: $5 \mathrm{~mm}$. .260 
Figure 33 - Radiographic image of Gorgasia thamani, Paratype, NSMT-P 68327, showing the number of vertebrae. Scale bar: $10 \mathrm{~mm}$.

Figure 34 - Radiographic image of Ophichthus obtusus, Holotype, NSMT-P 106574, showing the number of vertebrae. Scale bar: $10 \mathrm{~mm}$ 262

Figure 35 - Radiographic image of Protanguilla palau, USNM 396016, showing the number of vertebrae. Scale bar: $10 \mathrm{~mm}$

Figure 36 - Neurocranium of $\uparrow$ Anguillavus quadripinnis in lateral view (Belouze, 2003: Fig. 3). 263

Figure 37 - Pelvic girdle of $\uparrow$ Anguillavus quadripinnis in lateral view (Belouze, 2003: Fig. $14)$ .263

Figure 38 - Suspensorium of $\uparrow$ Anguillavus quadripinnis in lateral view (Belouze, 2002: Fig. 10) 264

Figure 39 - Branchial arches of Gorgasia punctata, CAS 20752, in lateral view. .264

Figure 40 - Lower jaw and adductor mandibulae complex of (A) Polyacanthonothus rissoanus, VIMS 4552, (B) Albula vulpes, MNRJ 37303, (C) Aldrovandia phalacra, VIMS 8390, and (D) Elops saurus, MNRJ 40531, in medial view. .265 
Figure 41 - Lower jaw and adductor mandibulae of (A) Coloconger meadi, UF 211407, (B) Protanguilla palau, USNM 396016, and (C) Derichthys serpentinus, USNM 444953, in medial view. AM pars epistegalis and AM pars substegalis highlighted.

Figure 42 - Anterior part of the body of Heteroconger camelopardalis, MZUSP 57611, left side view

Figure 43 - Anterior part of the body of Gymnomuraena zebra, SIO 62-8, left side view....268

Figure 44 - Anterior part of the body of Albula vulpes, MNRJ 37303, right side view. .269

Figure 45 - Anterior part of the body of Cyema atrum, SIO 66-546, right side view 270

Figure 46 - Neurocranium of Acromycter perturbartor, MNRJ 27115, in dorsal view. 271

Figure 47 - Anterior part of the body of Cyema atrum, ANSP uncat, in lateral view. 272

Figure 48 - Hyomandibular and muscles associated with Eurypharynx pelecanoides, SIO 7343, in lateral view .273

Figure 49 - Branchial arches of Kaupichthys sp., USNM 444952, in ventral view. 274 
Figure 50 - Branchial arches of Nemichthys scolopaceus, USNM 358874, in ventral view.

Figure 51 - Lower jaw and associated muscles of Cyema atrum, SIO 66-546, lateral view. 276

Figure 52 - Anterior part of the body of Neocyema sp., MCZ 165900, in lateral view.

Figure 53 - Anterior part of the body Coloconger meadi, UF 211407, in lateral view. 278

Figure 54 - Anterior part of the body Nemichthys scolopaceus, ANSP 158461, in lateral view. 279

Figure 55 - Anterior part of the body of Pythonichthys asodes, UF 228629, in lateral view. 280

Figure 56 - Anterior part of the body of Simenchelys parasitica, SIO 05-11, in lateral view. 281

Figure 57 - Anterior part of the body of Pythonichthys asodes, UF 228629, in lateral view.

Figure 58 - Branchial arches of Coloconger meadi, USNM 443687, in dorsal view 
Figure 59 - Branchial arch of Serrivomer sp. USNM 443689, in dorsal view. .284

Figure 60 - Branchial arches of (A) Albula vulpes, USNM 218871, and (B) Netastoma malanurum, USNM 405025, in ventral view. .285

Figure 61 - Branchial arches of (A) Cyema atrum, SIO66-546, and (B) Stemodium hypomelas, ANSP 152332, in ventral view. .286

Figure 62 - Scales of Protanguilla palau, USNM 396016. .287

Figure 63 - Scales of Anguilla anguilla (Pankhurst, 1982: Figure 6b). .287

Figure 64 - Strict consensus tree resultant from Implicit Weighting implied against homoplasy under K=7. Highlighted clades: Elopiformes (yellow), Albuliformes (green), Notacanthiformes (blue), Anguilliformes (red). .288

Figure 65 - Strict consensus tree resultant from Implicit Weighting implied against homoplasy under $\mathrm{K}=7$ (TNT graphics) .289

Figure 66 - Interrelationships of the Anguilliformes, strict consensus tree resultant from Implicit Weighting implied against homoplasy under $\mathrm{K}=7$. .291 


\section{CONTENTS}

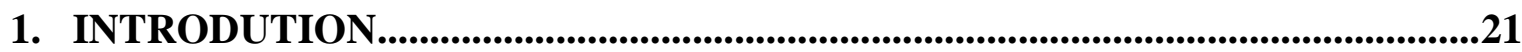

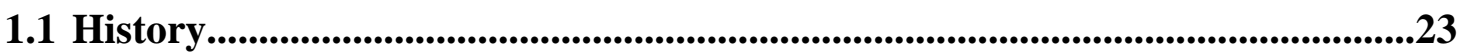

1.1.1 - Morphological and Anatomical Analyses........................................23

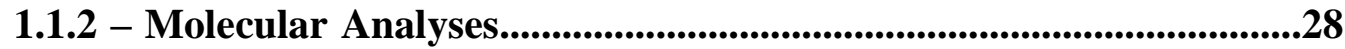

2. SCIENTIFIC JUSTIFICATION.....................................................................................30

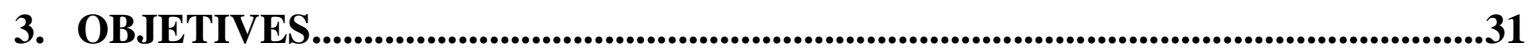

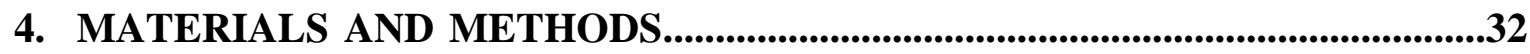

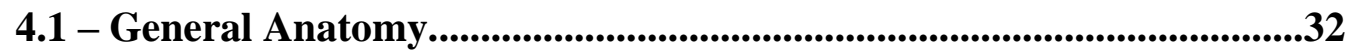

4.2 - Illustrations................................................................................................32

4.3 - Phylogenetic Analysis.............................................................................................33

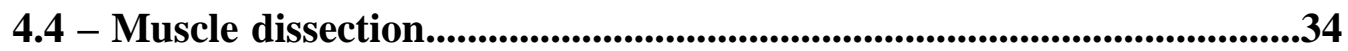

4.5 - Material Examined............................................................................36

4.6 - List of Used Abbreviations for Anatomical Structures.........................42

5. RESULTS..................................................................................................................................44

5.1 - Osteological Characters...................................................................44

5.1.1 - Neurocranium..................................................................................44

5.1 .2 - Sensory canals...............................................................................56

5.1 .3 - Suspensorium..........................................................................................59

5.1.4 - Opecular Series.................................................................................................76

5.1.5 - Ventral elements of the hyoid arch...............................................83

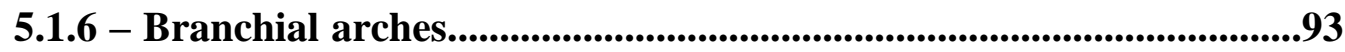

5.1.7 - Pectoral Girdle and paired fins........................................................106

5.1.8 - Dorsal, anal and caudal fins elements.....................................................118

5.1.9 - Vertebrates and spines bones................................................................130 
5.2 - Musculature

5.2.1 - Cephalic Muscles..........................................................................141

5.2.2 - Opercular Muscles...............................................................................154

5.2.3 - Hyoid Muscles...................................................................................158

5.2.4 - Branchial Muscles - Dorsal.....................................................................160

5.2.5 - Branchial Muscles - Ventral...............................................................174

5.3 - General Characters..........................................................................182

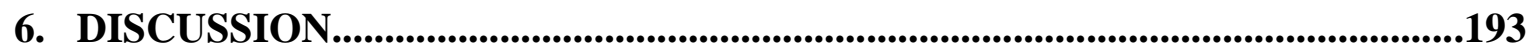

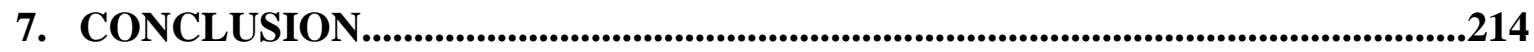

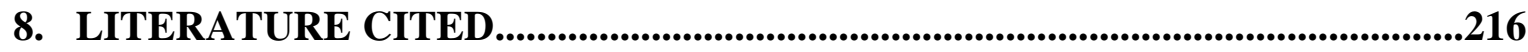

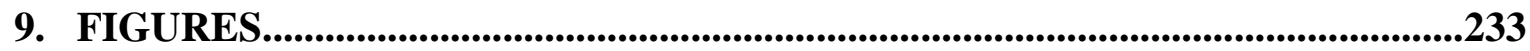

10. APPENDIX - QUALITATIVE CHARACTERS................................................293 


\section{INTRODUCTION}

Elopomorpha is composed of Elopiformes (tarpons), Albuliformes (bony fishes), Notacanthiformes (spiny eels) and Anguilliformes (eels, morays, congers, and gulper eels), the group occurs from tropical regions to polar seas, with most species marine or estuarine. The Anguilliformes comprises 1,009 species and 20 families in 156 genera (Fricke et al., 2019), being the most heterogeneous subgroup of Elopomorpha, comprising about $90 \%$ of its species (Figures 1 and 2). Anguilliformes occur in a broad array of habitats, including brackish water, reef environments, fossorial benthic, pelagic, and abyssal (Helfman et al., 2009). Wiley \& Johnson (2010) compiled six synapomorphies corroborating the Anguilliformes as a monophyletic group.

Feeding habits of anguilliform are as diverse as their anatomy. Although typically carnivorous, they include an enormous variety of resources, including zooplankton (e.g., Heteroconger, Gorgasia), crustacea and mollusks (e.g., Echidna, Eurypharynx), fish and cephalopods (e.g., Gymnothorax, Muraena), or generalist or necrophages (e.g., Anguilla, Simenchelys) (Helfman et al., 2009; Nelson et al., 2016). Their feeding mechanism was the subject of investigation, for example, some species of Echidna have the pharyngeal jaw system (a specialization of the fourth arch) into a shell-crushing mechanism (Mehta \& Wainwright, 2008). Other species can project their pharyngeal jaw as a functional second set of jaws to help food displacement to the esophagus (Mehta \& Wainwright, 2007; Mehta \& Wainwright, 2008; Johnson, 2019).

The bizarre anatomy of gulper eels (Saccopharyngoidei) has attracted attention. Both Eurypharyx and Saccopharynx can swallow prey with their tremendously swollen jaws, which can be over eight times the length of the skull (Nielsen et al., 1989). The Saccopharyngoidei specializations are so extreme that Tchernavin (1947) expressed doubts about the taxa therein being bony fishes. Helfman et al. (2009) noted that Saccopharyngoidei lacks a multitude of 
bones and bony complexes, such as opercular bones, symplectic, branchiostegals, maxillae, premaxillae, vomer, parasphenoid, scales, pelvic and pectoral girdles. The Monognathidae have additional unique specializations such as rostral fang and poisonous glands Bertelsen $\&$ Nielsen (1987).

The discovery of Protanguilla palau, prompted the anatomical diagnosis of an additional ten synapomorphies (two were previously maintained) for the Anguilliformes (Johnson et al., 2012; Springer \& Johnson, 2015):

1. body scales absent or embedded and arranged in a basket-weave fashion

2. Ethmoid fused with vomer

3. Pterotic extends anteriorly above prootic to contact pterosphenoid

4. Dermopalatine and autopalatine absent

5. Pectoral girdle displaced posteriorly

6. First pharyngobranchial absent and pharyngobranchials without uncinate processes

7. Gill arches free from braincase and displaced posteriorly

8. Opercular series characterized by a distinctive pattern

9. Uppermost branchiostegals curving dorsally behind

10. Posterior ceratohyal almost equal to or longer than anterior ceratohyal

11. Branchiostegals more numerous on the posterior than on the anterior ceratohyals

12. Posteriormost one to four branchiostegals with spatulate expansions distally

13. Dorsal part of suture between anterior and posterior ceratohyals deflected posteriorly

14. Interhyal absent

15. Angular, articular and retroarticular fused into a single bone

16. entopterygoid absent;

17. Post-temporal absent

18. Two pairs of upper pharyngeal tooth plates present and autogenous (not fused to pharyngobranchials) 
19. epurals absent;

20. one or no hypohyals;

21. dorsal and anal fins confluent;

22. less than eight rays in each caudal-fin lobe;

23. pyloric caecum absent;

24. nasal opening considerable separated, the posterior slightly anterior to the orbit;

25. branchial membrane united over isthmus, restricted opening;

26. Hypobranchial 3 cartilaginous or absent; accessory element 4 absent (lost independently in Albula and Lipogenys).

\section{1 - History}

\subsection{1 - Morphological and Anatomical Analyses}

One of the first studies about anguilliform osteology and morphology is Cope (1871, 1884), who named them Apoda subdivided into two groups: Enchelycephali (Anguillidae) and Colocephali (other eels, including Eurypharyngidae). Gill (1889a, b, 1890a, b, c, e) made a great series of publication on the anatomy and relationships of Muraenidae, Anguillidae, Muraenesocidae, Synaphobranchidae, and Notacanthiformes. Gill \& Ryder (1883, 1884) published two paper on saccopharyngoids, focused mostly on general anatomy and relationships with Lyomeri.

Regan (1909) proposed two new groups, the Halosauridae, and Notacanthidae + Lipogenys (=Heteromi). In the same publication, anguilloids (Apodes) were diagnosed by the lack of premaxillae, and anguimorph body, a fixed quadrat, the maxilla articulating with a fixed 
ethmo-vomer, and the pectoral girdle free from the neurocranium. Regan (1909) mentioned the presence of pre-maxillae in Derichthys and was "skeptical" about its inclusion in Anguilliformes, despite their similarities. Regan (1909) also proposed that Saccopharyngoidei (=Lyomeri), in lacking parietals, and having transverse processes ankylosed with vertebral centra and restricted gill-openings based on hyomandibular position, and broad skull, are derived from Apodes. Regan (1912) reviewed his character and proposed an identification key to the 16 families of Apoda. The author also positioned Saccopharyngoidei in Lyomeri, divided Anguilliformes (=Apoda) into two suborders: Anguilloidei and Nemichthyoidei.

Bertin $(1932 a, b, 1934,1936,1938)$ published a series of works on adults and larvae of Anguilliformes, mostly saccopharyngoids and described a new family, Monognathidae. The author drew an interesting parallel between the jaw mechanism in Saccopharynx and snakes. Saccopharyngoids (=Lyomeri) was the object of a study by Tchernavin (1947), with a focus on bones, muscles, branchial arches, and viscera, with ensuing implications for phylogenetic relationships.

Berg (1940) changed Apoda to Anguilliformes, and Saccopharyngiformes to Lyomeri. The same author divided Anguilliformes into two suborders: Anguilloidei (ventral fin absent) and Nemichthyoidei (supraoccipital absent, supracleithrum absent, and scapula and coracoid unossified).

Trewavas (1933) did substantial research on different families of eels and proposed a new classification of fresh eels. Greenwood et al. (1966) proposed four anguilliform groups: Anguilloidei, Saccopharyngoidei, Elopiformes (Elopoidei and Albuiloidei) and Notacanthiformes, and first used the name Elopomorpha. Later, Patterson \& Rosen (1977) included Saccopharyngoidei in Anguilliformes, corroborating Elopomorpha as a monophyletic group and discussing the relationship among the orders (Figure 3a). Lauder \& Liem (1983) proposed Anguilliformes based on the following features: (1) leptocephalus larvae; (2) angular and retroangular fused on lower jaw; and (3) rostral and prenasal ossicles. The Elopomorpha 
was divided in Albuloidei, with Albulidae + (Notacanthidae + Halosauridae) and Anguilloidei (Anguillidae + Saccopharyngoidei).

The extensive book publication about larvae generated three relevant studies about Elopomorpha and Anguilliformes were performed by (1984), Smith (1984) and Leiby (1984), which the first one raised some osteological characters. Castle (1984) pointed out the characters for Anguilliformes relationships leptocephalus nevertheless without an algorithm or cladogram, many of them overlapping characteristics. In another chapter, Smith (1984) raised larvae characters of Elopiformes, Noatacanthiformes, and Anguilliformes. Such a study was the first phylogenetic analysis using parsimony algorithm, with outstanding results. In this proposed, Serrivomeridae and Nemichthyidae formed a monophyletic group, another group formed by Muraenidae, Myrocongridae and Chlopsidae (=Xenocongridae), and additional clade with anguillids, moringuids, and heterenchelyids. Smith (1984) indicated that Colocongridae and Muraenosocidae share congrids characters, a similar hypothesis with Nettastomatids. Essential thorough research performed by Leiby (1984) was an extensive larvae examination, establishing a comprehensive anatomical feature among Ophichthidae species and increasing knowledge on leptocephalus structures development fusion, absence, or loss, such as premaxillae and ectopterygoid. Furthermore, that research provides a cladogram based on the light of the results of the leptocephalus of the 51 genera of ophichthids and corroborating the two subfamilies (Ophichthinae and Myrophinae) proposed by McCosker (1977).

Böhlke et al. (1989) provided taxonomic and osteological s of adults (part 1) and larvae (part 2) of Anguilliformes and Saccopharyngiformes. All families of Anguilliformes and Saccopharyngiformes were included, with identification keys, species diagnosis, and geographical distributions (Bertelsen et al., 1989; McCosker et al., 1989a, b; Robins \& Robins, 1989a, b; Smith, 1989a, b, c, d, e, f, g, h; Smith et al., 1989; Tighe, 1989). Robins (1989) raised 42 osteology and external morphological items, cited the Anguilliformes relationship with outgroup Elopomorpha, based on six synapomorphies, notwithstanding his survey not included Saccopharyngiformes within eels, nevertheless only four are synapomorphies (listed below). 
However, it was not performance characters exhaustive searches, matrix analysis, or characters polarization. That contribution divided Anguilliformes into three suborders: Congroidei, with frontal bones, fused; Muraenoidei, with frontal bones, separated, branchial elements reduced, lateral line absent and scales absent; and Anguilloidei, with frontal separated. Saccopharyngiformes also was divided into two suborders: Cymatoidei, with lateral pores absent, relatively small and compressed body; and Saccopharyngoidei, with quadrate extremely long and pharynx extensible (Figure 3b).

Forey et al. (1996) listed morphological and molecular characters of Elopomorpha placing Saccopharyngoidei within Anguilliformes (Figure 3c). Forey et al. (1996) raised six synapomorphies for Anguilliformes:

1. extrascapular canal absent;

2. symplectic fused to quadrate;

3. branchial arches displaced posteriorly and free from neurocranium;

4. gill rakers absent;

5. pelvic girdles and fins absent;

6. body scales absent or embedded and arranged in basket-weave fashion.

In an unpublished thesis, Belouze (2002) compiled characters from many previous studies, including osteology, nerves, and circulatory system, in a total of 123 characters. The phylogenetic hypothesis included 30 Recent and 20 fossil anguilliforms, plus outgroup taxa (Figure 4). Shortly after that, Belouze et al. (2003) offered an extensive anatomical of $\dagger$ Anguillavus quadripinnis Hay, 1903, $\uparrow$ A. mazeni and $\dagger$ Luenchelys minimus.

The first study on the cephalic musculoskeletal system in Anguilliformes was Eagderi (2010), an unpublished Ph.D. thesis. It included 67 specimens in seven different families: Anguillidae, Nettastomatidae, Heterenchelyidae, Congridae, Moringuidae, Ophichthidae and Eurypharyngidae. 
Branchial arches in anguilliforms were studied by Nelson $(1966,1967)$, who suggested the recognition of three different lineages: Anguilloid, Synaphobranchoidei, and Congroidei. Nelson (1966) also recognized two subfamilies in Muraenidae: Muraninae (basibranchials and hypobranchials absent) and Uropterygiinae (basibranchials absent and only hypobranchials 1 and 2 present). Nelson (1967) described the muscles of five families in Anguilliformes (Congridae, Anguillidae, Moringuidae, Xenocongridae, and Muraenidae), reportings the presence of the retractor dorsal and ventral muscles in Congridae and a second insertion of the vertebrae associated with pharyngeal jaws in Muraninae.

Springer \& Johnson (2004) published a comprehensive, detailed comparative anatomy of the dorsal branchial arches in various groups of bony fishes (Teleostei), including one species each of Congridae, Anguillidae, and Synaphobranchidae. The authors clarify various homology and nomenclatural problems.

Another unique and poorly explored clade is the pugnose eel Simenchelys parasitica Gill 1879 (family Synaphobranchidae, subfamily Simenchelyinae). That deep-water species has a unique behavior among Anguilliformes and is a parasite and scavenger. Eadgeri et al. (2016) offered detailed musculoskeletal anatomy and tissue analysis comparing Ilyophis brunneus Gilbert 1891 (Ilyophinae) and Synaphobranchus brevidorsalis Günther 1887 (Synaphobranchinae).

Mehta \& Wainright (2007a, b, 2008), based on species of Muraenidae, described the functional role of branchial arches as a second jaw (=pharyngeal jaw or raptorial jaw). The upper and lower tooth plates, pharyngobranchial, ceratobranchial and epibranchial of the fourth arch; the muscles associated as levator internus 4 , levator externus 4 , obliquus dorsalis 4 , rectus communis, dorsal retractor, sternohyoideus, and adductor dorsalis 5, are so that the entire structure is capable of projecting until the middle of the orbit. Mehta \& Wainwright (2008) reported on the ecomorphology of ten species of Muraenidae, piscivorous, or shell-crushers. Carnivorous species exhibits long jaws, small heads, long curved tooth, processing food with the pharyngeal jaws. Shell-crushing morays have short jaws, short, round teeth, and handle prey 
with the oral jaws. Johnson (2019) provided an extensive revision of Muraenidae branchial muscles, reviewing terminology and anatomical nomenclature of Mehta \& Wainright (2007a, b, 2008)

New anguilliform synapomorphies were proposed by Johnson et al. (2012), along with the of Protanguilla palau, known only from reef caves in Palau, Pacific Ocean. The new taxon is the sister group to the rest of the order, with three plesiomorphies found only in Cretaceous Anguilliformes: gill rakers (not seen in living Anguilliformes). The authors propose that Protanguilla diverged from the remaining anguilliforms in the Triassic-Jurassic, about 220 million years ago (Figure 5). Additional synapomorphies for Anguilliformes from branchial arches muscles suggested by Springer \& Johnson (2015).

Da Silva \& Johnson (2018) recently explored the pectoral-fin skeleton. The authors described the pectoral girdles of Anguilla and Nemychthys, correcting previous misinterpretations.

Despite the plethora of work on Recent Anguilliformes, merely two authors focused on morphological characters (Böhlke et al., 1989; Belouze, 2002).

\subsection{2 - Molecular Analyses}

The molecular results proposed by Obermiller \& Pfeiffer (2003) did not recover Elopomorpha as a monophyletic group (Figure 6), also Saccopharyngoidei in their order. The hypotheses of the relationships of Anguilliformes inferred from morphological characters according to Filleul \& Lavoué (2002) pointed out Muraenidae as basal clade and Saccophayngiformes within Anguilliformes (Figure 7). 
Tang \& Fielitz (2012) proposed Saccopharyngoidei (sensu Forey et al., 1996) as a sister group to Anguilloidei (Moringuidae, Serrivomeridae, Nemichthyidae, Saccopharyngoidei, and Anguillidae), Congridae as a paraphyletic group and Protanguilla as a sister group of Synaphobranchidae (Figure 8).

After decades of pitched contention over the interrelationships of Anguilliformes, Chen et al. (2014) and Santini et al. (2013) tested some maximum likelihood analyses using nuclear and mitochondrial gene sequences to evaluate the phylogenetic relationship in Elopomorpha (Figures 9 and 10). In the two papers, Chen et al. (2014) and Santini et al. (2013) gathered Protanguilla, and Synaphobranchidae in the same clade, and this clade as the sister group of the rest of all Anguilliformes, likewise Congridae and Muraenosocidae non-monophyly. In the light of what was written by Chen et al. (2014) and Santini et al. (2013) grouping saccopharyngoids and anguillids together. It may perhaps be observed that the position of "Thalassenchelys" in Chen et al. (2014) as the sister group of Coloconger, however, in Santini et al. (2013) the big mouth larvae are related to Derichthys. All researches mentioned herein recovered the Muraenosocidae and Ophichthidae together.

Many investigations have strived to determine the position of the most bizarre group of the deep-water fish, the Saccopharyngoidei, composed of Cyematidae, Monognathidae, Eurypharyngidae, and Saccopharyngidae. Their remarkable modifications include exceptional bone reductions, fusions, or losses (Tchernavin, 1947a, b; Nilsen et al., 1989). The leptocephalus stage of saccopharyngoids is still undescribed. Poulsen et al. (2018), based on mitogenomic sequence data, performed molecular and morphological analysis over "Leptocephalus holti," the incertis sedis larvae, however, the authors pointed out these specimens as larval stage of one-jaw eels of the Monognathidae. Poulsen et al. (2018) also generated a cladogram in which Neocyematidae is more closely related to Eurypharyngidae and Saccopharyngidae. In that study, Protanguilla is not a basal group among Anguilliformes, but rather sister group of Synaphobranchidae. 
Lü et al. (2019) sequenced the complete mitochondrial genome of Ophichthus brevicaudatus Wu \& Jin 1981 and proposed a hypothesis of phylogenetic relationships of Anguilliformes including 45 species in 16 families, but not included Protanguilla palau in their analysis, also chose Saccopharngoidei as an outgroup. The results pointed out that a group composed by Synaphobranchidae + (Heretenchelyidae + (Myrocongridae + Muraenidae) another monophyletic clade gathering Nemychthidae + (Serrvomeridae + Anguillidae) this one as a sister group of all Anguilliformes (Figure 11).

Worthy of mentioning in all molecular analysis presented here, the Congridae not recovered as monophyletic, and the Muraenosocidae and Ophichthidae hypothesized as sister groups. 


\section{LITERATURE CITED}

ALLIS, E. P. 1897. The cranial muscles and cranial and first spinal nerves in Amia calva. Journal of Morphology, 12(3): 487-808.

ARRATIA, G. 1997. Basal teleosts and teleostean phylogeny. Palaeo Ichthyologica, 7: 1-168.

BELOUZE, A. 2002. Comprehension morphologique et phylogenetique des taxons actuels et fossiles rapportes aux anguilliformes (Poissons, Teleosteens). Unpulished doctoral dissertation, Lyon, 401 p.

BELOUZE, A.; GAYET, M. \& ATALLAH, C. 2003a. Les premiers Anguilliformes. II. Paraphylie du genre Urenchelys Woodward, 1900 et relations phylogénétiques. Geobios, 36: $351-378$.

BELOUZE, A.; GAYET, M. \& ATALLAH, C. 2003b. Les premiers Anguilliformes: I. Révision des genres Cénomaniens Anguillavus Hay, 1903 et Luenchelys nov. gen. Geobios, 36(3): 241-273.

BERG, L. S. 1940. Classification of fishes, both recent and fossil. Transactions of the Institute of Zoology, Academy of Sciences of the USSR, 5:87-517.

BERTELSEN, E.; NIELSEN, J. G. \& SMITH, D. G. 1989. Suborder Saccopharyngoidei Families Saccopharyngidae, Eurypharyngidae and Monognathidae. In: BÖHLKE, E. B. (ed.). Fishes of the Western North Atlantic: part 9, volume 1: Orders Anguilliformes and Saccopharyngiformes. Yale University, New Haven, CT. Sears Foundation for Marine Research. (Memoir, 1). pp. 636-655.

BERTIN, L. 1932a. Bases anatomiques de la classification des poissons Apodes appartenant tiu sous-ordres des Lyomères. Comptes rendus de l'Académie des Sciences, 195: 1422-4. 
BERTIN, L. 1932b. Des analogies entre le squelette maxillaire des Saccopharynx et des Eurypharynx, poissons Apodes, et celui des reptiles ophideux. Bulletin de la Société Zoologique de France, 57(2): 145-54.

BERTIN, L. 1934. Les poissons Apodes appartenant au sous-ordres des Lyomères. DanaReport, 3: 1-60.

BERTIN, L. 1936. Un nouveau genre de poissons Apodes caracterize par l'absence de machoire superieure. Bulletin de la Société Zoologique de France, 61: 533-540.

BERTIN, L. 1938. Formes nouvelles et formes larvaires de poissons Apodes appartenmt EU sous-ordre des Lyombres. Dana-Report, 15: 1-26.

BETANCUR-R. R.; BROUGHTON, R. E.; WILEY, E. O.; CARPENTE, K. J.; LÓPEZ, A.; LI, C.; HOLCROFT, N. I.; ARCILA, M.; SANCIANGCO, M.; CURETON, J. C.; ZHANG, F.; BUSER, T.; CAMPBELL, M. A.; BALLESTEROS, J. A.; ROA-VARON, A.; WILLIS, S.; BORDEN W. C.; ROWLEY, T.; RENEAU, P. C.; HOUGH, D. J.; LU, G.; GRANDE, T; ARRATIA, G. \& ORTÍ, G. 2013. The Tree of Life and a New Classification of Bony Fishes. PLOS Currents Tree of Life, 1-41. doi: 10.1371/currents.tol.53ba26640df0ccaee75bb165c8c26288

BÖHLKE, E. B. 1989a. Methods and Terminology. In: Fishes of the Western North Atlantic: part 9, volume 1: Orders Anguilliformes and Saccopharyngiformes. BÖHLKE, E. B. ed. New Haven, CT: Yale University, Sears Foundation for Marine Research. (Memoir, 1). 1-7.

BÖHLKE, E. B. (ed.).1989b. Order Anguilliformes. In: Fishes of the Western North Atlantic: part 9, volume 1: Orders Anguilliformes and Saccopharyngiformes. BÖHLKE, E. B. ed. New Haven, CT: Yale University, Sears Foundation for Marine Research. (Memoir, 1). 25-627.

BÖHLKE, E. B.; MCCOSKER J. E. \& BÖHLKE. J. E. 1989. Family Muraenidae. In Fishes of the Western North Atlantic: part 9, volume 1: Orders Anguilliformes and 
Saccopharyngiformes. BÖHLKE, E. B. ed. New Haven, CT: Yale University, Sears Foundation for Marine Research. (Memoir, 1). 104-206.

BRITZ, R., \& HOFFMANN, M. 2006. Ontogeny and homology of the claustra in Otophysan Ostariophysi (Teleostei). Journal of Morphology, 267(8): 909-923.

CHAPMAN, W. M. 1944. The osteology of the Pacific deep-bodied anchovy, Anchoa compressa. Journal of Morphology, 74(2): 311-329.

CHEN, J-N.; LÓPEZ, J. A.; LAVOUÉ, S.; MIYA, M. \& CHEN, W-J. 2013. Phylogeny of the Elopomorpha (Teleostei): evidence from six nuclear and mitochondrial markers. Molecular Phylogenetics and Evolution, 70: 152-161.

COPE, E. D. 1871. Contribution to the Ichthyology of the Lesser Antilles. Transactions of the American Philosophical Society, 14(1): 445-483.

COPE, E. D. 1884. On the structure of the skull in the elasmobranch fishes. Proceedings of the American Philosophical Society, 21 (116): 572-590.

DAGET, J. 1964. Le crâne des Téléostéens. Muséum national d'Histoire naturelle, Paris. 177 p.

DATOVO, A. \& BOCKMANN, F. A., 2010. Dorsolateral head muscles of the catfish families Nematogenyidae and Trichomycteridae (Siluriformes: Loricarioidei): comparative anatomy and phylogenetic analysis. Neotropical Ichthyology, 8(2): 193-246.

DATOVO, A. \& CASTRO, R. M. C., 2012. Anatomy and evolution of the mandibular, hyopalatine, and opercular muscles in characiform fishes (Teleostei: Ostariophysi). Zoology (Jena), 115: 84-116.

DATOVO, A. \& RIZZATO, P. P. 2018. Evolution of the facial musculature in basal ray-finned fishes. Frontiers in Zoology, 15(1). doi:10.1186/s12983-018-0285-6. 
DATOVO, A. \& VARI, R. P. 2013. The jaw adductor muscle complex in teleostean fishes evolution homologies and revised nomenclature (Osteichthyes: Actinopterygii). Plos One, 8(4): $1-23$.

DE BEER, G. R. 1937. The development of vertebrate skull. University of Chicago Press, Chicago. $760 \mathrm{p}$

DE PINNA, M. C. C. 1991. Concepts and tests of homology in the cladistic paradigm. Cladistics, 7: 367-394.

DE SCHEPPER, N.; ADRIAENS D. \& DE KEGEL, B., 2005. Moringua edwardsi (Moringuidae: Anguilliformes): cranial specialization for head-first burrowing? Journal of Morphology, 266: 356-368.

DE SCHEPPER, N., DE KEGEL, B. \& ADRIAENS D., 2007. Pisodonophis boro (Ophichthidae: Anguilliformes): specialization for head-first and tail-first burrowing? Journal of Morphology, 268: 112-126.

EAGDERI, S. \& ADRIAENS, D. 2010. Cephalic morphology of Pythonichthys macrurus (Heterenchelyidae: Anguilliformes): specializations for head-first burrowing. Journal of Morphology, 271(9): 1053-1065.

EAGDERI, S. 2010. Structural diversity in the cranial musculoskeletal system in Anguilliformes: an evolutionary-morphological study. Parts 1 \& 2. Unpublished doctoral dissertation. Universiteit Gent. i-xi, 246p.

EAGDERI, S.; CHRISTIAENS, J.; BOONE, M.; JACOBS, P. \& ADRIAENS, D. 2016. Functional morphology of the feeding apparatus in Simenchelys parasitica (Simenchelyinae: Synaphobranchidae), an alleged parasitic eel. Copeia, 104(2): 421-439. 
FARRIS, J. S. 1983. The Logical basis of phylogenetics analysis. In: Proceedings of the Second Meeting of the Willi Hennig Society. PLATNICK, N. \& FUNK, V. A. eds.: Columbia University Press, New York. Advances in Cladistics, 2:7-36.

FILLEUL, A. \& LAVOUÉ, S. 2001. Basal teleosts and the question of elopomorph monophyly. Morphological and molecular approaches. Comptes rendus de l'Académie des Sciences, Sciences de la vie / Life Sciences 324 (2001) 393-399

FINK, S. V. \& FINK, W. L. 1981. Interrelationships of the Ostariophysan fishes (Teleostei). Zoological Journal of the Linnean Society, 72: 297-353.

FOREY, P.L. 1973. Relationships of elopomorphs. Zoological Journal of Linnean Society, 53(1 Suppl.):351-368.

FOREY P. L.; LITTLEWOOD D. T. J.; RITCHIE P. \& MEYER A. 1996. Interrelationships of elopomorph fishes. In: Interrelationships of Fishes. STIASSNY, M. L. J.; PARENTI, L. R. \& JOHNSON, G. D. eds. San Diego: Academic Press, 175-191.

FRICKE, R.; ESCHMEYER, W. N. \& VAN DER LAAN, R. (eds) 2019. Eschmeyer's Catalog of Fishes: Genera, Species, References [electronic resource]. San Francisco, CA: California Academy of Sciences, Institute for Biodiversity Science and Sustainability. Online Version Updated: 1 July 2019. Available at:

http://researcharchive.calacademy.org/research/ichthyology/catalog/fishcatmain.asp Accessed: 27 July 2019.

FUJITA, K. 1990. The caudal skeleton of teleostean fishes. Tokyo: Tokai University Press. $897 \mathrm{p}$.

GILL, T. 1889a. The Halosauroid fishes typical of a special order. American Naturalist, 23: 1015-1016.

GILL, T. 1889b. The Notocanthid fishes as representatives of a peculiar order. American Naturalist, 23: 1016-1017. 
GILL, T. 1890a. The osteological characteristics of the family Simenchelydae. Proceedings of the United States National Museum, 817: 239-242.

GILL, T. 1890b. The osteological characteristics of the family Anguillidae. Proceedings of the United States National Museum, 803: 157-160.

GILL, T. 1890c. The osteological characteristics of the family Synaphobranchidae. Proceedings of the United States National Museum, 804: 161-164.

GILL, T. 1890d. The osteological characteristics of the family Muraenida. Proceedings of the United States National Museum, 805: 165-170.

GILL, T. 1890e. The osteological characteristics of the family Muraenesocida. Proceedings of the United States National Museum, 815: 231-234.

GILL, T. \& RYDER, J. A. 1883. On the anatomy and relations of the Eurypharyngidae. Proceedings of the United States National Museum, 6: 262-273.

GILL, T. \& RYDER, J. A. 1884. On the literature and systematic relations of the saccopharyngoid fishes. Proceedings of the United States National Museum, 7: 48-65.

GOLOBOFF, P. A.; CARPENTER, J. M.; SALVADOR ARIAS, J. \& ESQUIVEL D. R. M. 2008. Weighting against homoplasy improves phylogenetic analysis of morphological data. Cladistics, 24(5): 758-773.

GOLOBOFF, P., FARRIS, S., \& NIXON, K. 2018. TNT, A free program for phylogenetic analysis. Cladistics, 24 (5): 774-786.

GOSLINE, W. A. 1951. The osteology and classification of the ophichthid eels of the Hawaiian Islands. Pacific Science, 5(4): 298-320. 
GOSLINE, W. A. 1971. Functional Morphology and Classification of Teleostean Fishes. Honolulu, University Press of Hawaii. 208 p.

GREENWOOD, P. H. 1971. Hyoid and ventral gill arch musculature in osteoglossomorph fishes. Bulletin of the British Museum of the Natural History, 22(1): 1-35.

GREENWOOD, P. H.; ROSEN, D. E.; WEITZMAN, S. H.; \& MYERS, G. S. 1966. Phyletic studies of Teleosteans fishes with a provisional classification of living forms. Bulletin of the American Museum of Natural History, 131(4): 339-456.

HELFMANN, G. S.; COLLETE, B. B.; FACEY, D. E. \& BOWEN, B. W., 2009. Diversity of Fishes. Biology, Evolution, and Ecology. 2nd Edition. Oxford: Wiley-Blackwell. i-xiv, 720p.

HENNIG, W. 1950. Grudzüge einer theorie der Phylogenetischen Systematik. Berlin, Deutscher Zentralverlag. 370p.

HENNIG, W. 1966. Phylogenetic Systematics. Urbana, University of Illinois Press. 263p.

HILTON, E. J. 2002. Comparative osteology and phylogenetic systematics of fossil and living bony-tongue fishes (Actinopterygii, Teleostei, Osteoglossomorpha). Zoological Journal of the Linnean Society, 137(1): 1-100.

HILTON. E. J \& LAVOUÉ, S. 2018. A review of the systematic biology of fossil and living bony-tongue fishes, Osteoglossomorpha (Actinopterygii: Teleostei). Neotropical ichthyology, 16(3). doi: 10.1590/1982-0224-20180031.

HULET, W. H. 1978. Structure and functional development of the eel Leptocephalus Ariosoma balearicum (De La Roche, 1809). Philosophical Transactions of the Royal Society of London: Series B, 282(987): 107-138. 
INOUE J. G.; MIYA, M; TSUKAMOTO K. \& NISHIDA M. 2003. Evolution of the deep-sea gulper eel mitochondrial genomes: large-scale gene rearrangements originated within the eels. Molecular Biology \& Evolution, 20(11): 1917-1924.

JOHNSON, G. D.; IDA, H.; SAKAUE, J.; SADO, T.; ASAHIDA, T. \& MIYA, M. 2012. A "living fossil" eel (Anguilliformes: Protanguillidae, fam. nov.) from an undersea cave in Palau. Proceeding of the Royal Society B, 279: 934-943.

JOHNSON, G. D. 2019. Revisions of anatomical descriptions of the pharyngeal jaw apparatus in moray eels of the Family Muraenidae (Teleostei: Anguilliformes). Copeia, 107(2):341-357

KANEHIRA, N.; IMAMURA, H. \& YABE, M. 2012. Phylogenetic relationships of the suborder Notacanthoidei (Teleostei: Albuliformes) reassessed from osteological characters, with a proposed new classification. Memoirs of the Faculty of Fisheries Sciences, Hokkaido University, 54(1/2): 1-31.

LAUDER, G. V. \& LIEM, K. F. 1983. The evolution and interrelationships of the actinopterygian fishes. Bulletin of the Museum of Comparative Zoology, 150(3): 95-195.

LEIBY, M. M. 1979. Morphological development of the eel Myrophis punctatus (Ophichthidae) from hatching to metamorphosis, with emphasis on the developing head skeleton. Bulletin Of Marine Science, 29(4): 509-521.

LÜ, Z.; ZHU, K.; JIANG, H.; LU, X.; LIU, B.; YE, Y.; JIANG, L. L. \& GONG, L. 2019. Complete mitochondrial genome of Ophichthus brevicaudatus reveals novel gene order and phylogenetic relationships of Anguilliformes. International Journal of Biological Macromolecules, 135: 609-618.

MADDISON, W. P. \& MADDISON, D. R. 2010. Mesquite: a modular system for evolutionary analyses v. 2.73. http://www.mesquiteproject.org 
MCCOSKER, J. E. 1977. The osteology, classification, and relationships of the eel family Ophichthidae. Proceedings of the California Academy Sciences Series 4, 41(1): 1-123.

MCCOSKER, J. E., BÖHLKE, E. B. \& BÖHLKE, J. 1989. Family Ophichthidae. In Fishes of the Western North Atlantic: part 9, volume 1: Orders Anguilliformes and Saccopharyngiformes. BÖHLKE, E. B. ed. New Haven, CT: Yale University, Sears Foundation for Marine Research. (Memoir, 1). 254-412.

MCDOWELL, S. 1973. Family Halosauridae. In: Fishes of the Western North Atlantic. BÖHLKE, E. B. ed. Yale University, New Haven, CT. Sears Foundation for Marine Research, 1(6): 32-123.

MEHTA R. S. 2009. Ecomorphology of the moray bite: relationship between dietary extremes and morphological diversity. Physiological and Biochemical Zoology, 82: 90-103.

MEHTA R. S. \& WAINWRIGHT P. C. 2007a. Biting releases constraints on moray eel feeding kinematics. Journal of Experimental Biology, 210: 495-504.

MEHTA R. S. \& WAINWRIGHT P. C. 2007b. Raptorial jaws in the throat help moray eels swallow large prey. Nature, 449: 79-82.

MEHTA R. S. \& WAINWRIGHT P. C. 2008. Functional Morphology of the Pharyngeal Jaw Apparatus in Moray Eels. Journal of Experimental Biology, 210: 495-504.

MELO, M. R. S., 2007. A new synaphobranchid eel (Anguilliformes: Synaphobranchidae) from Brazil, with comments on the species from the western South Atlantic. Copeia, (2): 315-323.

NEAR, T. J.; EYTAN, R. I.; DORNBURG, A.; KUHN, K. L.; MOORE, J. A.; DAVIS, M. P.; WAINWRIGHT, P. C.; FRIEDMAN, M. \& SMITH, W. L. 2013. Resolution of ray-finned fish phylogeny and timing of diversification. PNAS, 109(34): 13698-13703.

NELSON G. J. 1966a. Gill arches of teleostean fishes of the order Anguilliformes. Pacific Science, 20: 391-408. 
NELSON, G. J. 1966b. Osteology and Relationships of the Eel, Neenchelys buitendijki. Copeia, 1966(2): doi:10.2307/1441141

NELSON, G. J. 1967a. Branchial muscles in representatives of five eel families. Pacific Science, 21: 348-363.

NELSON, G. J. 1967b. Branchial muscles in some generalized teleostean fishes. Acta Zoologica, 48(3): 277-278.

NELSON, G. J. 1969. Gill arches and the Phylogeny of Fishes, with notes with Classification of Vertebrates. Bulletin of the American Museum of Natural History, 144(4): 475-522.

NELSON, J. S. 2006. Fishes of the World. John Wiley \& Sons Inc., NewYork. 601 p.

NIELSEN, J. G.; BERTELSEN, E. \& JESPERSEN, Å. 1989. The biology of Eupharynxry pelecanoides (Pisces, Eurypharyngidae). Acta Zoologica (Stockholm), 70(3): 187-197.

NIXON, K. C. \& CARPENTER, J. M. 1993. On outgroup. Cladistics, 9: 413-426.

NORMAN, J. R. 1926. The development of the chondrocranium of the eel (Anguilla vulgaris), with observations on the comparative morphology and development of the chondrocranium in bony fishes. Philosophical Transactions of the Royal Society of London. Series B, 214: 369464.

OBERMILLER L. E. \& PFEILER E. 2003. Phylogenetic relationships of elopomorph fishes inferred from mitochondrial ribosomal DNA sequences. Molecular Phylogenetics and Evolution, 26(2): 202-14.

PATTERSON, $C$ \& JOHNSON, G. D. 1995. The intermuscular bones and ligaments of teleostean fishes. Smithsonian Contributions to Zoology, 559: 1-83. 
PATTERSON, C. \& ROSEN, D. E. 1977. Review of ichyodectiform and other Mesozoic teleost fishes and the theory and practice of classifying fossils. Bulletin American Museum Natural History, 158: 81-172.

POULSEN, J. Y.; MILLER, M. J.; SADO, T.; HANEL, R.; TSUKAMOTO, K. \& MIYA, M. 2018. Resolving deep-sea pelagic saccopharyngiform eel mysteries: identification of Neocyema and Monognathidae leptocephali and establishment of a new fish family "Neocyematidae" based on larvae, adults and mitogenomic gene orders. PLoS One,_13(7): e0199982.

REECE, J. S.; BOWEN, B. W.; SMITH, D. G. \& LARSON, A. 2010. Molecular phylogenetics of moray eels (Muraenidae) demonstrates multiple origins of a shell-crushing jaw (Gymnomuraena, Echidna) and multiple colonizations of the Atlantic Ocean. Molecular Phylogenetics and Evolution, 57: 829-835.

REGAN, C. T. 1909. The classification of teleostean fishes. Annals and Magazine of Natural History, 8(43): 75-86.

REGAN, C. T. 1910. The caudal fin of the Elopidae and of some other teleostean fishes. Annals and Magazine of Natural History, 5(28): 354-358.

REGAN, C. T. 1912. The osteology and classification of the teleostean fishes of the Order Apodes. Annals and Magazine of Natural History, 10(58): 377-387.

ROBINS, C. H. 1971. The comparative morphology of the synaphobranchid eels of the straits of Florida. Proceedings of the Academy of Natural Sciences of Philadelphia, 123: 153-204.

ROBINS, C. H. 1989. Family Derichthyidae. In: Fishes of the Western North Atlantic: part 9, volume 1: Orders Anguilliformes and Saccopharyngiformes. BÖHLKE, E. B. ed. New Haven, CT: Yale University, Sears Foundation for Marine Research. (Memoir, 1). 420-431. 
ROBINS, C. H. \& ROBINS, C. R. 1971. Osteology and relationships of the eel Family Macrocephenchelyidae. Proceedings of the Academy of Natural Sciences of Philadelphia, 123: $127-150$.

ROBINS, C. H. \& ROBINS, C. R. 1976. New genera and species of dysommine and synaphobranchine eels (Synaphobranchidae) with an analysis of the Dysomminae. Proceedings of the Academy of Natural Sciences of Philadelphia, 127: 249-280.

ROBINS, C. H. \& ROBINS, C. R. 1989. Family Synaphobranchidae. In: Fishes of the Western North Atlantic: part 9, volume 1: Orders Anguilliformes and Saccopharyngiformes. BÖHLKE, E. B. ed. New Haven, CT: Yale University, Sears Foundation for Marine Research. (Memoir, 1). 207-253.

ROBINS, C. R. 1989. The phylogenetic relationships of the anguilliform fishes. In: Fishes of the Western North Atlantic: part 9, volume 1: Orders Anguilliformes and Saccopharyngiformes. BÖHLKE, E. B. ed. New Haven, CT: Yale University, Sears Foundation for Marine Research. (Memoir, 1). 9-23.

SANTINI, F.; KONG, X.; SORENSON, L.; CARNEVALE, G.; MEHTA, R. S. \& ALFARO, M. E. 2013. A multi-locus molecular timescale for the origin and diversification of eels (Order: Anguilliformes). Molecular Phylogenetics and Evolution, 69: 884-894.

SCHUH, R. T. \& BROWER, A.V. Z. 2009. Biological Systematics: Principles and Applications, 2nd Edition. Cornell University Press. 328 p.

SHELYAGIN, D. I. 2010. Osteology of Halosauridae (Notacanthiformes). Journal of Ichthyology, 50(7): 512-528.

SLOWINSKI, J. B. 1993. "Unordered" versus "ordered” characters. Systematic Biology, 42(2): 155-165. 
SMITH, D. G. 1984. Elopiformes, Notacanthiformes and Angulilliformes: relationships. In: Ontogeny and Systematics of Fishes. MOSER, H. G.; RICHARDS, W. J.; COHEN, D. M.; FAHAY, M. P.; KENDALL JR, A. W. \& RICHARDSON, S. L. eds. Ontogeny and systematics of fishes Based on an International Symposium dedicated to the memory of Elbert Halvor Ahlstrom (Special Publication Number 1). New York, American Society of Ichthyologists and Herpetologists. 94-102.

SMITH, D. G. 1989a. Families: Saccopharnygidae, Eurypharyngidae, and Monognathidae: Leptocepahli. In: Fishes of the Western North Atlantic: part 9, volume 2: Lepitocephali. BÖHLKE, E. B. ed. New Haven, CT: Yale University, Sears Foundation for Marine Research. (Memoir, 1). 948-954.

SMITH, D. G. 1989b. Family Anguillidae. In: Fishes of the Western North Atlantic: part 9, volume 1: Orders Anguilliformes and Saccopharyngiformes. BÖHLKE, E. B. ed. New Haven, CT: Yale University, Sears Foundation for Marine Research. (Memoir, 1). 25-47.

SMITH, D. G. 1989c. Family Congridae. In: Fishes of the Western North Atlantic: part 9, volume 1: Orders Anguilliformes and Saccopharyngiformes. BÖHLKE, E. B. ed. New Haven, CT: Yale University, Sears Foundation for Marine Research. (Memoir, 1). 460-567.

SMITH, D. G. 1989d. Family Moringuidae. In: Fishes of the Western North Atlantic: part 9, volume 2: Lepitocephali. BÖHLKE, E. B. ed. New Haven, CT: Yale University, Sears Foundation for Marine Research. (Memoir, 1). 699-703.

SMITH, D. G. 1989e. Family Muraenosocidae. In: Fishes of the Western North Atlantic: part 9, volume 1: Orders Anguilliformes and Saccopharyngiformes. BÖHLKE, E. B. ed. New Haven, CT: Yale University, Sears Foundation for Marine Research. (Memoir, 1). 432-440.

SMITH, D. G. 1989f. Family Cyematidae. In: Fishes of the Western North Atlantic: part 9, volume 1: Orders Anguilliformes and Saccopharyngiformes. BÖHLKE, E. B. ed. New Haven, CT: Yale University, Sears Foundation for Marine Research. (Memoir, 1). 630-635. 
SMITH, D. G. 1989g. Family Chlopsidae. In: Fishes of the Western North Atlantic: part 9, volume 1: Orders Anguilliformes and Saccopharyngiformes. BÖHLKE, E. B. ed. New Haven, CT: Yale University, Sears Foundation for Marine Research. (Memoir, 1). 72-97.

SMITH, D. G. 1989h. Family Nettastomatidae In: Fishes of the Western North Atlantic: part 9, volume 1: Orders Anguilliformes and Saccopharyngiformes. BÖHLKE, E. B. ed. New Haven, CT: Yale University, Sears Foundation for Marine Research. (Memoir, 1). 568-612.

SMITH, D. G. 1989i. Family Colocongridae. In: Fishes of the Western North Atlantic: part 9, volume 1: Orders Anguilliformes and Saccopharyngiformes. BÖHLKE, E. B. ed. New Haven, CT: Yale University, Sears Foundation for Marine Research. (Memoir, 1). 413-419.

SMITH, D. G. 1989j. Family Myrocongridae. In: Fishes of the Western North Atlantic: part 9, volume 1: Orders Anguilliformes and Saccopharyngiformes. BÖHLKE, E. B. ed. New Haven, CT: Yale University, Sears Foundation for Marine Research. (Memoir, 1). 98-103.

SMITH, D. G. \& NIELSEN, J. G. 1989. Family Nemichthydae. In: Fishes of the Western North Atlantic: part 9, volume 1: Orders Anguilliformes and Saccopharyngiformes. BÖHLKE, E. B. ed. New Haven, CT: Yale University, Sears Foundation for Marine Research. (Memoir, 1). 441-460.

SPRINGER, V. G. \& JOHNSON, G. D. 2004. Study of the dorsal gill-arch musculature of teleostome fishes, with special reference to the Actinopterygii. Bulletin of the Biological Society of Washington, 11: p. i-vi, 1-260, pl. 1-205.2.

SPRINGER, V. G., \& G. D. JOHNSON. 2015. The gill-arch musculature of Protanguilla, the morphologically most primitive eel (Teleostei: Anguilliformes), compared with that of other putatively primitive extant eels and other elopomorphs. Copeia103: 595-620.

STIASSNY, M. L. J.; PARENTI, L. \& JOHNSON, G. D. 1996. Interrelationships of Fishes. Academic Press. California. I-XIII, 496p. 
SWOFFORD, D. L. \& MADDISON, W. P. 1987. Reconstructing ancestral character states under Wagner parsimony. Mathematical and Bioscience, 87: 199-229.

TANG, K. L. \& FIELITZ, C. 2012. Phylogeny of moray eels (Anguilliformes: Muraenidae), with a revised classification of true eels (Teleostei: Elopomorpha: Anguilliformes). Mitochondrial DNA, 24(1):55-66. Epub: 2012 Sep 12. doi: 10.3109/19401736.2012.710226.

TAYLOR, W. R. \& VAN DYKE, G. C. 1985. Revised Procedures for staining and clearing small fishes and other vertebrates for bone and cartilage study. Cybium, 9(2): 107-119.

TCHERNAVIN, V. V. 1947a. Six specimens of Lyomeri in the British Museum (with notes on the skeleton of the Lyomeri. Zoological Journal of the Linnean Society, 41(279): 287-350.

TCHERNAVIN, V. V. 1947b. Further notes on the structure of the bony fishes of the order Lyomeri (Eurypharynx). Zoological Journal of the Linnean Society, 41(280): 377-393.

WAINWRIGHT, P. C.; SMITH, W. L.; PRICE, S. A.; TANG, K. L.; FERRY, L. A.; SPARKS J. S. \& NEAR, T. J. 2012. The evolution of pharyngognathy: a phylogenetic and functional appraisal of the pharyngeal jaw key innovation in labroid fishes and beyond. Systematic Biology, 61(6): 1000-1027.

WEITZMAN, S. H. 1962. The osteology of Brycon meeki, a generalized characid fish, with an osteological definition of the family. Stanford Ichthyological Bulletin, 8(1): 1-77.

WILEY, E. O. 1979. Ventral gill arch muscles and the interrelationships of gnathostomes, with a new classification of Vertebrata. Zoological Journal of Linnean Society, 67: 149-179.

WILEY, E. O. 1981. Phylogenetics: the theory and practice of phylogenetic systematics. John Wiley \& Sons, New York. vi,439 pp.

WILEY, E. O. \& JOHNSON, G. D. 2010. A teleost classification based on monophyletic groups. In: Origin and phylogenetic interrelationships of teleosts. Nelson J.S., Schultze H.P., Wilson M.V.H. (eds.). Verlag Dr. Friedrich Pfeil, Munich, Germany. 123-182. 
WILEY, E. O. \& LIEBERMAN, B. S. 2011. Phylogenetics: the theory of phylogenetic systematics. John Wiley \& sons, Inc, New Jersey. xv,406 pp.

WILKINSON, M. 1992. Ordered versus unordered. Cladistics, 8: 375-385.

WINTERBOTTOM, R. 1973. A descriptive synonymy of the striated muscles of the Teleostei. Proceedings of the Academy of Natural Sciences of Philadelphia, 125: 225-317. 